\title{
Kecerdasan Emosional Tokoh Perempuan Muslimah dalam Novel Assalamualaikum Beijing Karya Asma Nadia
}

\author{
The Emotional Intelligence of A Muslim Women in Asma Nadia's Novel \\ "Assalamualaikum Beijing"
}

\author{
Galuh Dilah Kurnia ${ }^{1, *}$ dan Azizatuz Zahro, \\ ${ }^{1,2}$ Pendidikan Bahasa, Sastra Indonesia, dan Daerah \\ Fakultas Sastra, Universitas Negeri Malang \\ *Correspondence email: galuhdilah@gmail.com
}

Received: 20 Juni 2020 Revised: 22 Juli 2020 Accepted: 19 Oktober 2020

\begin{abstract}
This study is intended to describe the intelligence of emotional, that the main character has in the novel entitled "Assalamualaikum Beijing" by Asma Nadia. This study used qualitative approach with the study of literary psychology. The qualitative approach using the study of literary psychology is chosen because this study is meant to describe the phenomena in form of words and language regarding the mental aspects of the main character. A type and method of this study were using document study and content analysis. This study belonged to the document study because the researcher was reviewing the written document in the form of a novel entitled "Assalamualaikum Beijing" by Asma Nadia. The data analysis is done by presenting the data, interpreting the data, and drawing the conclution. The results of this study showed that the emotional intelligence of the Muslim women in the novel covered (1) the ability of managing the emotions, (2) the ability of motivating herself, and (3) the ability of building relationship. The ability to manage emotions in the form of the ability to control impulses and overcome anxiety and sadness. The ability to motivate themselves in the form of a character's desire to succeed and take advantage of other situations, obstacles, and self-problems as motivation. The ability to build relationships is demonstrated through the interaction of characters in creating close relationships, maintaining relationships, building comfort and moving others.
\end{abstract}

Keywords: emotional intelligence, woman figure, muslim women, novel, Asma Nadia

\begin{abstract}
Abstrak: Penelitian ini bertujuan mendeskripsikan kecerdasan emosional tokoh perempuan muslimah dalam novel Assalamualaikum Beijing karya Asma Nadia. Penelitian ini menggunakan pendekatan kualitatif dengan kajian psikologi sastra. Pendekatan kualitatif dengan kajian psikologi sastra dipilih karena penelitian ini mendeskripsikan fenomena-fenomena dalam bentuk kata-kata dan bahasa mengenai aspek-aspek kejiwaan tokoh. Jenis penelitian dan metode yang digunakan adalah studi dokumen dan analisis isi. Metode analisis data dilakukan dengan memaparkan data, menginterpretasi data, dan menarik kesimpulan. Hasil penelitian menunjukkan bahwa kecerdasan emosional tokoh perempuan muslimah dalam novel meliputi (1) kemampuan mengelola emosi, (2) kemampuan memotivasi diri, dan (3) kemampuan membina hubungan. Kemampuan mengelola emosi berupa kemampuan mengendalikan dorongan serta mengatasi kecemasan dan kesedihan. Kemampuan memotivasi diri berupa keinginan tokoh untuk berhasil dan memanfaatkan situasi lain, hambatan, serta masalah diri sebagai motivasi. Kemampuan membina hubungan ditunjukkan melalui interaksi tokoh dalam menciptakan kedekatan hubungan, mempertahankan hubungan, membangun kenyamanan hingga menggerakkan orang lain.
\end{abstract}

Kata kunci: kecerdasan emosional, tokoh perempuan, muslimah, novel, Asma Nadia

To cite this article:

Kurnia, G. D., \& Zahro, A. (2021). Kecerdasan Emosional Tokoh Perempuan Muslimah dalam Novel Assalamualaikum Beijing Karya Asma Nadia. Diglosia: Jurnal Kajian Bahasa, Sastra, dan Pengajarannya, 4(1), 37-48. https://doi.org/10.30872/diglosia.v4i1.89 


\section{A. PENDAHULUAN}

Beragamnya pandangan tentang perempuan seiring dengan perkembangan waktu menjadikan perempuan sebagai sosok yang menarik disoroti. Perempuan tidak hanya memiliki kedudukan yang begitu penting dalam aspek kehidupan, tetapi juga menjadi sosok menarik dalam karya sastra di mata penulis. Sesuai dengan perkembangan novel di Indonesia, perempuan menjadi sosok yang paling banyak digarap dalam karya sastra. hal. ini menggambarkan bahwa sosok perempuan memang mewarnai khasanah kesusastraan Indonesia khususnya novel (Novera, 2017). Novel memiliki makna luar biasa sebagai cerminan dari sebuah realitas kehidupan. Sesuai dengan pendapat (Nurgiyantoro, 2005), novel sendiri merupakan karya yang bersifat realistis serta mengandung nilai psikologi yang mendalam sehingga dapat terus berkembang.

Sosok perempuan yang menempati posisi istimewa juga tercermin dalam agama Islam. Saat Islam membicarakan posisi perempuan dalam kehidupan, Islam menempatkan sosok perempuan ke dalam tiga misi penting. Misi tersebut yakni menjadi sumber ketenangan, sumber kasih sayang, dan guru bagi anak-anaknya (Asy-Sya'rawi, 2013). Perempuan muslimah pastinya menjadi sosok yang dijadikan panutan bagi semua kalangan. Perempuan muslimah yang dimaksud merupakan sosok perempuan menarik, unggul, cerdas yang berdasarkan syariat Islam. Pengarang berusaha maksimal untuk mengarahkan pembaca kepada gambarangambaran realitas kehidupan tokoh perempuan muslimah melalui kecerdasan yang terkandung dalam novel untuk dijadikan sebagai sumber inspirasi bagi pembaca. Pembaca mampu menilai sisi baik maupun sisi buruk, serta mengambil hikmah dan amanat dari cerita yang disampaikan pengarang melalui sebuah novel (Deswika, 2012).

Novel Assalamualaikum Beijing karya Asma Nadia menarik dikaji karena kecerdasan emosional tokoh perempuannya yang mampu menginspirasi para pembaca untuk menjadi pribadi yang lebih baik. Tokoh Asma mampu melewati ujian secara bertubi-tubi, namun ia sama sekali tak pernah mengeluh sedikitpun. Kecerdasan emosional tokoh Asma yang mampu mengelola emosi serta memotivasi diri untuk bangkit dapat dijadikan inspirasi dan panutan bagi pembaca dalam menghadapi lika-liku kehidupan.

Terdapat tiga penelitian sejenis yang pernah dilakukan. Pertama, penelitian Marwan (2019) berjudul Kecerdasan Emosi Tokoh dalam Novel Setegar Ebony Karya Asih Karina. Penelitian ini memfokuskan pada kecerdasan emosi tokoh yang dipengaruhi oleh id, ego, dan superego dengan menggunakan kajian teori psikoanalitik. Kedua, penelitian Setyorini (2016) berjudul Kepribadian Tokoh Utama dan Nilai Pendidikan Kerja Keras pada Novel Entrok Karya Okky Madasari dan Relevansinya dengan Pembelajaran Sastra di Perguruan Tinggi (Kajian Psikologi Sastra). Penelitian ini memfokuskan pada aspek kepribadian, nilai pendidikan, dan kerelevansian dengan pembelajaran sastra. Ketiga, penelitian Supandu (2017) berjudul Perempuan dalam Novel Dakwah: Kajian Karya Asma Nadia dalam Perspektif Hall. Penelitian tersebut bertujuan untuk mendeskripsikan representasi dan posisi tokoh perempuan dengan menggunakan kajian teori representasi.

Persamaan penelitian ini dengan penelitian sebelumnya terletak pada metode yang digunakan, yakni menggunakan metode analisis isi dengan menganalisis dan mendeskripsikan isi novel. Penelitian ini juga memiliki perbedaan dengan penelitian 
sebelumnya. Perbedaan terletak pada fokus penelitian dan kajian teori yang digunakan. Penelitian ini mendeskripsikan kecerdasan emosional tokoh perempuan muslimah yang berkaitan dengan kemampuan tokoh mengelola emosi, memotivasi diri, membina hubungan dalam novel Assalamualaikum Beijing dengan menggunakan kajian psikologi sastra.

Kecerdasan yang dimiliki perempuan muslimah adalah wujud karunia perkembangan akal budi. Kecerdasan merupakan kemampuan memahami dunia, berpikir rasional, dan menggunakan sumber-sumber secara efektif pada saat dihadapkan dengan tantangan. Mujib \& Mudzakir (2002) mengartikan kecerdasan sebagai kemampuan (al-Qudrah) dalam memahami sesuatu secara tepat dan sempurna. Menurut Hanafi (2010), kecerdasan emosional adalah salah satu kecerdasan yang melekat dalam diri seseorang. Kecerdasan ini berperan penting dalam kesuksesan seseorang. Kecerdasan emosional mampu memberi kesadaran mengenai perasaan milik diri sendiri dan juga perasaan milik orang lain, dengan memberi rasa empati, motivasi, kemampuan menanggapi perasaan secara tepat. Kecerdasan emosi mampu membuat seseorang jujur kepada diri sendiri, memiliki hubungan yang baik dengan sesama, serta mampu memberikan panduan nurani bagi jalan hidup yang hendak ditempuh.

Emosi diartikan sebagai pergolakan pikiran, perasaan, nafsu dari setiap keadaan mental yang hebat atau meluap-luap (Daryanto, 2006). Dapat diartikan bahwa emosi memiliki kecenderungan dari pikirannya yang bergolak untuk melakukan suatu tindakan. Menurut Goleman (2006), kecerdasan emosi mampu menentukan seberapa baik seseorang mampu menggunakan kecerdasan-kecerdasan lain manapun yang dimiliki. Emosi manusia terletak pada hati terdalam tiap orang, oleh karena itu kecerdasan emosional mampu memberikan pemahaman yang cukup mendalam mengenai diri sendiri dan orang lain (Agustian, 2004).

Bagian dari kecerdasan emosional yakni kemampuan mengelola emosi, memotivasi diri, dan membina hubungan. Mengelola emosi merupakan suatu kemampuan seseorang dalam mengendalikan dan menangani emosinya sendiri. Dalam hal. ini, seseorang mampu mengontrol suasana hati, seperti kesedihan, kecemasan, atau amarah dan dorongan lainnya (Goleman, 2006). Tujuan mengelola emosi adalah mewujudkan keseimbangan antara emosi dalam diri manusia.

Selanjutnya, kemampuan memotivasi diri. Konsep penting dari teori motivasi adalah pada kekuatan yang ada dalam diri manusia. Dalam aspek memotivasi diri sendiri, individu harus mampu mengendalikan gangguan yang datang, bersikap optimis, dan mampu memfokuskan perhatian pada hal. yang sedang dikerjakan. Seseorang yang mampu memotivasi diri, akan menjadikan hambatan sebagai hal. yang memotivasi diri untuk melakukan sesuatu hal. dengan baik (Goleman, 2006). Kemampuan memotivasi diri biasanya ditandai dengan kemampuan memiliki keinginan untuk berhasil, menjadikan hambatan sebagai tantangan, serta menjadikan masalah sebagai dorongan.

Kemudian, kemampuan membina hubungan. Seseorang dengan keterampilan sosial yang baik tentunya mampu berinteraksi dengan baik. Keterampilan tersebut merupakan kecakapan sosial yang mendukung keberhasilan dalam pergaulan dengan orang lain. Kemampuan sosial ini memungkinkan seseorang membentuk dan mempertahankan hubungan, untuk menggerakkan orang lain, membina kedekatan hubungan, meyakinkan, serta membuat orang-orang lain merasa nyaman (Goleman, 2006). Dalam membina hubungan juga diperlukan adanya kepedulian, 
seperti sikap seseorang yang dengan baik merespon bahkan mengutamakan perasaan orang lain. Dapat disimpulkan bahwa kecerdasan emosional adalah suatu kemampuan untuk memahami perasaan diri sendiri dan perasaan orang lain serta kemampuan untuk memotivasi diri sendiri dan mengelola emosi dengan sebaikbaiknya.

\section{B. METODE}

Penelitian ini menggunakan pendekatan kualitatif dengan kajian psikologi sastra. Pendekatan kualitatif dipilih karena mengeksplorasi fenomena-fenomena yang bersifat deskriptif. Fenomena yang dimaksud meliputi hal-hal yang dialami, khususnya aspek kejiwaan tokoh perempuan muslimah dalam novel dengan cara mendeskripsikan dalam bentuk kata-kata dan bahasa. Jenis penelitian yang digunakan adalah studi dokumen. hal. ini dikarenakan peneliti mengkaji sebuah dokumen tertulis berupa novel Assalamualaikum Beijing karya Asma Nadia. Data penelitian ini berupa kutipan teks dalam novel Assalamualaikum Beijing karya Asma Nadia. Kutipan teks tersebut berupa paragraf narasi maupun dialog antartokoh yang menunjukkan adanya kecerdasan emosional tokoh perempuan muslimah.

Pengumpulan data penelitian ini menggunakan teknik dokumentasi dengan bantuan instrumen tabel. Teknik dokumentasi dilakukan dengan cara mengumpulkan data melalui pembacaan secara cermat, membaca kembali keseluruhan isi novel, menandai dan mencatat data-data berupa kutipan, melakukan pengklasifikasian dan pengkodean data, kemudian memasukkan data ke dalam tabel instrumen analisis data. Metode yang digunakan dalam penelitian ini adalah analisis isi. Metode analisis data dilakukan dengan memaparkan data, menginterpretasi data, dan menarik kesimpulan. Uji keabsahan data penelitian ini menggunakan triangulasi teori dan diskusi teman sejawat.

\section{PEMBAHASAN}

Hasil penelitian ini dibagi menjadi tiga, yakni (1) kemampuan tokoh perempuan muslimah mengelola emosi, (2) kemampuan tokoh perempuan muslimah memotivasi diri, dan (3) kemampuan tokoh perempuan muslimah membina hubungan.

\section{Kemampuan Mengelola Emosi}

Tokoh perempuan muslimah yang memiliki kemampuan emosional, tentunya akan handal dalam mengelola emosi yang muncul pada dirinya. Emosi manusia sendiri terletak pada hati terdalam tiap orang Secara psikologis, emosi dialami sebagai reaksi dari suatu hal. hal. ini bisa bersifat menyenangkan maupun tidak menyenangkan, seperti bahagia, marah, sedih, khawatir, cemas dan sebagainya. Tokoh perempuan muslimah dengan kemampuan mengelola emosi yang baik mampu mengendalikan emosi yang muncul pada waktu tertentu. Seperti, seseorang mampu mengontrol suasana hati, seperti kesedihan, kecemasan, atau amarah dan dorongan lainnya (Goleman, 2006). Tujuan mengelola emosi adalah mewujudkan keseimbangan antara emosi dalam diri manusia. Kemampuan mengelola emosi tokoh perempuan muslimah, yakni tokoh Asma dalam novel meliputi mampu 
mengendalikan dorongan hati, mampu mengatasi kecemasan, serta mampu menangani kesedihan.

\section{Tabel 1. Hasil Penelitian Kemampuan Mengelola Emosi}

\begin{tabular}{|c|c|c|}
\hline No & Fokus & Hasil \\
\hline 1 & $\begin{array}{l}\text { Kemampuan } \\
\text { tokoh perempuan } \\
\text { muslimah } \\
\text { mengelola emosi }\end{array}$ & $\begin{array}{l}\text { a. Kemampuan tokoh perempuan muslimah mengendalikan } \\
\text { dorongan hati yang muncul pada saat tertentu. } \\
\text { b. Kemampuan tokoh perempuan muslimah mengatasi kecemasan } \\
\text { melalui usaha yang dilakukannya sendiri. } \\
\text { c. Kemampuan tokoh perempuan muslimah menangani kesedihan } \\
\text { dengan bersikap tegar dan tidak larut dalam keterpurukan. }\end{array}$ \\
\hline
\end{tabular}

Tokoh Asma sebagai perempuan muslimah telah mengendalikan dorongan hati dalam dirinya. hal. ini terlihat melalui sikap tokoh yang mampu mengendalikan dorongan hati ketika dirinya menginginkan kehadiran seseorang untuk menemani perjalanannya, dengan menepuk dahinya pelan. hal. ini sengaja dilakukannya untuk menyadarkan dirinya agar tidak terlena oleh dorongan hati yang tiba-tiba muncul tanpa disengaja. Dapat diketahui melalui kutipan: "Wajah lain datang tanpa diundang. Sepasang mata memanjang dengan senyum tak hanya di bibir, tetapi juga matanya. Asma menepuk dahinya pelan" (Nadia, 2016, hal. 57).

Asma juga mampu mengendalikan dorongan hatinya dengan cara melenyapkan perasaan yang mulai hadir dalam hatinya pada lelaki yang baru dikenalnya, serta mengalihkan pandangan ketika dirinya mulai hanyut dalam pesona lelaki asal China yang bernama Zhongwen. Sesuai dengan kutipan: "Tentang Zhongwen, mungkin, perasaan ini lebih baik dilenyapkan sebelum semakin tumbuh dan akan terlalu menyakitkan ketika harapan tak seiring kenyataan" (Nadia, 2016, hal. 207).

Selain mampu mengendalikan dorongan hati, tokoh Asma sebagai perempuan muslimah juga mampu mengatasi kecemasan dalam diri dengan caranya sendiri. Kecemasan sendiri merupakan latihan terhadap apa-apa yang barangkali tidak beres dan bagaimana mengatasinya (Goleman, 2006). Asma tengah berusaha menangani berbagai pikirannya yang campur aduk. Dalam hal. ini, yang ia lakukan adalah membuka matanya lebar-lebar dengan mencoba menerobos gelap malam yang mulai membentang. Ia melihat segala yang tampak pada luar jendela bus. Seperti, langit biru malam, pemandangan, serta deretan lampu besar kecil yang muncul bergantian. Pemandangan tersebut membuat pikirannya tenang. Lambat laun, pikirannya pun mengalir teratur, sama seperti helaan napasnya. Pikirannya tidak lagi sibuk dengan beberapa hal. yang membuat campur aduk. Sebagai tokoh perempuan muslimah, ia tidak ingin membiarkan kecemasan menguasai dirinya hingga menyebabkan terjadinya hal-hal yang tidak diinginkan. hal. ini dapat dilihat melalui kutipan: "Asma membuka mata lebar-lebar, mencoba menerobos gelap malam yang mulai membentang. Berharap langit biru tua akan melarutkan berbagai pikirannya yang campur aduk" (Nadia, 2016, hal. 12).

Tokoh Asma tidak hanya mengatasi kecemasan yang hadir dalam dirinya melalui usahanya sendiri. Melainkan, Asma juga menangani kesedihan yang dialaminya. Satu-satunya suasana hati yang pada umumnya benar-benar diusahakan untuk dijauhi adalah kesedihan (Goleman, 2006). Asma telah berusaha mati-matian untuk menangani kesedihan atas kabar buruk yang diterima dari calon suaminya. Sebagai seorang perempuan muslimah, ia tidak melampiaskan kesedihannya begitu 
saja. Ia justru menangani kesedihan tersebut dalam diam, dengan mengumpulkan keping demi keping hatinya yang beterbangan. Dalam hal. ini, Asma tak ingin mengekspresikan kesedihannya di depan lelaki yang telah menghancurkan segala harapan dan mimpi-mimpinya. Sesuai dengan kutipan: "Cerita yang jika boleh tak hendak dipercayainya. Sementara dalam diam, gadis itu berusaha mengumpulkan keping demi keping hati yang beterbangan" (Nadia, 2016, hal. 63).

Tokoh Asma menangani kesedihan yang diterimanya bukan hanya dari sang kekasih saja, melainkan juga dari ayahnya sendiri. Ketika ayahnya bahkan pergi meninggalkan rumah, Mama, dan juga dirinya, Asma tidak menitikkan air mata sama sekali. Padahal, sudah jelas, hati siapa yang tak terluka melihat sang ayah meninggalkan dirinya demi tinggal bersama perempuan lain. Sosok ayah yang seharusnya menjadi panutan justru memberikan luka dalam bagi keluarganya. Mama tahu itu. Namun, tidak seperti yang dibayangkannya, Asma terlihat cukup tegar. Sesuai dengan kutipan: "Bahkan ketika ayahnya meninggalkan rumah untuk tinggal dengan perempuan lain. Asma tidak menitikkan air mata" (Nadia, 2016, hal. 129).

Kesedihan yang ditimbulkan oleh suatu kehilangan mempunyai dampak tertentu yang berbeda-beda (Goleman, 2006). Dari pemikiran tokoh lain pun, tercermin bahwa Asma adalah seorang perempuan muslimah yang tegar dan selalu berusaha untuk tidak larut dalam kesedihan.

\section{Kemampuan Memotivasi Diri}

Seseorang dengan kecerdasan emosional yang baik akan mampu mengendalikan gangguan yang datang, bersikap optimis, dan mampu memfokuskan perhatian pada hal. yang sedang dijalani. Kemampuan inilah yang disebut dengan kemampuan memotivasi diri. Seseorang yang mampu memotivasi diri, akan menjadikan hambatan sebagai hal. yang memotivasi diri untuk melakukan sesuatu hal. dengan baik (Goleman, 2006). Konsep penting dari teori memotivasi adalah pada kekuatan yang ada dalam diri manusia itu sendiri.

Pernyataan tersebut sesuai dengan yang dilakukan oleh tokoh Asma dalam novel berjudul Assalamualaikum Beijing. Kemampuan tokoh perempuan muslimah dalam memotivasi diri ditunjukkan melalui keinginan yang dimilikinya untuk berhasil, kemampuan tokoh dalam menjadikan situasi lain maupun masalah diri yang dialaminya sebagai suatu dorongan untuk menjadikan dirinya bangkit, dan menjadikan hambatan yang diperolehnya sebagai suatu tantangan. Menurut Goleman (2006), kumpulan perasaan antusiasme, gairah, dan keyakinan diri untuk mencapai keberhasilan merupakan ciri pada kemampuan memotivasi diri.

\section{Tabel 2. Hasil Penelitian Kemampuan Memotivasi Diri}

\begin{tabular}{|c|c|c|}
\hline No & Fokus & Hasil \\
\hline 1. & $\begin{array}{l}\text { Kemampuan } \\
\text { tokoh perempuan } \\
\text { muslimah } \\
\text { memotivasi diri }\end{array}$ & $\begin{array}{l}\text { a. Keinginan kuat yang disertai usaha dari tokoh perempuan } \\
\text { muslimah agar berhasil mencapai cita-cita yang diimpikannya. } \\
\text { b. Kemampuan tokoh perempuan muslimah menjadikan situasi lain } \\
\text { sebagai motivasi diri untuk bangkit. } \\
\text { c. Kemampuan tokoh perempuan muslimah menjadikan masalah } \\
\text { atau hambatan sebagai suatu tantangan tersendiri untuk } \\
\text { ditaklukan. }\end{array}$ \\
\hline
\end{tabular}


Tokoh Asma yang memiliki keinginan untuk berhasil dapat dilihat dari semangatnya ketika meneruskan perjalanan yang cukup melelahkan. Meskipun sempat kehabisan napas, dia tidak kehabisan semangat untuk berhasil mencapai tujuan dari perjalanan panjang yang telah ditempuhnya. Sesuai dengan kutipan: "Meskipun sempat kehabisan napas karena liukan anak tangga yang seakan tak berakhir, semangat gadis itu untuk tidak menyerah tersulut" (Nadia, 2016, hal. 58). Tujuan yang akan membawanya pada sejumlah pemandangan yang apik. Motivasi dapat menjadi dorongan untuk menimbulkan perilaku tertentu yang terarah kepada pencapaian suatu tujuan tertentu (Emda, 2017).

Asma juga memiliki keinginan yang kuat untuk menggapai mimpinya, terlepas dari kondisi tubuhnya yang sedang tidak sehat. Mimpi yang paling ingin ia wujudkan adalah memberikan kebanggaan kepada Mama sebelum usianya berakhir, seperti kutipan: "Memberikan kebanggaan kepada Mama sebelum usianya berakhir. Satu draf buku yang ditulisnya susah payah, kadang dibantu Sekar mengetik, sudah siap dikirimkan ke penerbit" (Nadia, 2016, hal. 207). Sebagai perempuan muslimah, ia paham betul bahwa dirinya memiliki kewajiban untuk membahagiakan ibu yang telah mengandung, melahirkan, sekaligus membesarkan dirinya. Ia semakin memiliki keinginan yang kuat setelah mengetahui kondisi tubuhnya yang mungkin tidak bertahan lama karena penyakit kronisnya. Bahkan, ia telah menulis satu draf buku dengan susah payah hingga buku yang telah ditulisnya sudah siap dikirimkan ke penerbit. Menurut Asma, dirinya tidak memiliki kesempatan untuk bermalasmalas. Terlalu banyak mimpi yang ingin dicapai dengan kondisi tubuh dan usia terbatas yang dimiliki Asma.

Tokoh Asma tidak hanya memiliki keinginan untuk berhasil, melainkan ia juga menjadikan situasi lain dari luar dirinya sebagai dorongan untuk menjadikannya pribadi yang lebih baik. Motivasi dapat dirangsang oleh faktor dari luar, tetapi motivasi itu tumbuh di dalam diri seseorang (Emda, 2017). Asma yang sedang berada di titik terbawah dalam hidupnya, tidak membuatnya merasa menjadi orang yang paling menderita. Ia melihat dan membandingkan apa yang dialaminya dengan situasi lain yang jauh lebih buruk darinya.

Asma sempat terpuruk di kamar dengan bermandi air mata dan mogok makan. Namun, kemudian, ia melihat situasi lain yang lebih jauh terpuruk darinya. Ia melihat masih banyak orang yang kesusahan untuk makan, sebab tidak memiliki apapun untuk dijadikan sebagai makanan. Sesuai dengan kutipan "Rasanya tak pantas mengurung diri, dan merasa sulit menelan nasi sesuap pun, sementara begitu banyak orang susah yang bahkan tak mempunyai apa-apa untuk dimakan." (Nadia, 2016, hal. 76). hal. tersebut tentunya menjadi pukulan berat bagi Asma. Masih banyak peristiwa yang jauh lebih tragis dari kisahnya, yang menjadikan kesedihannya semakin tak pantas untuk ditangisi terus menerus.

Saat ia merasa betapa sepinya dunia karena tak mampu mendengar suara apapun, dari situlah ia melihat kondisi para tuna rungu yang harus merasakan kesepian seumur hidupnya. Namun, para tuna rungu tetap memiliki kekuatan untuk terus menjalani kehidupan yang sunyi. hal. itulah yang membuat Asma mensyukuri keadaannya saat ini, sekaligus memberi kekuatan pada dirinya. Tuli yang dialaminya hanya sementara, tidak selamanya. Ternyata, masih banyak yang jauh lebih menderita darinya. Berikut ini kutipannya: "Perlu waktu, tetapi Asma bersyukur hanya mengalami tuli sementara. Betapa sepi dunia bagi mereka yang tak bisa 
mendengar. Kejadian pagi tadi membawa ke jenjang syukur lain" (Nadia, 2016, hal. 183).

Hal tersebut menjadikan motivasi bagi Asma untuk berpikir optimis. Optimisme, seperti harapan, berarti memiliki pengharapan yang kuat bahwa segala masalah kehidupan akan tuntas (Goleman, 2006). Ia juga dihadapkan oleh pasien muda yang tidak memiliki siapapun untuk menemani, dari hal. tersebut Asma merasakan bahwa nikmat Allah yang diperoleh melalui kehadiran Mama dan sahabatnya (Sekar) adalah sebuah anugerah yang patut disyukuri. Melalui hal. tersebut, Asma semakin bersyukur dan menjadikannya situasi lain tersebut menjadi dorongan bagi dirinya untuk tetap kuat dalam menjalani cobaan. Berikut ini kutipannya: "Di rumah sakit dia sempat berkenalan dengan seorang gadis berusia empat belas tahun, sementara tak seorang pihak pun menemani. Dia lebih beruntung, pikir Asma." (Nadia, 2016, hal. 209).

Asma juga memotivasi diri dengan menjadikan masalah yang dialami sebagai dorongan. Masalah patah hati yang dialami Asma justru menjadikan motivasi baginya untuk melewati masalah tersebut. Patah hati yang dialaminya menjadikan ia harus mencari obat penawar luka dan berusaha move on, melanjutkan hidup sesegara mungkin, meski sulit. Berikut kutipannya: "Dia tahu, setiap yang patah hati harus segera mencari obat penawar luka. Dan, bahwa mustahil hati terobati, tanpa berusaha move on, melanjutkan hidup sesegera mungkin, betapa pun sulit. Hijrah dari masa lalu" (Nadia, 2016, hal. 133). Salah satu fungsi motivasi ialah menyeleksi perbuatan, yakni menentukan perbuatan-perbuatan apa yang harus dikerjakan guna mencapai tujuan (Emda, 2017). Patah hati membuat Asma sebagai perempuan muslimah membulatkan tekadnya untuk hijrah dari masa lalu yang kelam menuju pada kebaikan. Hijrah dari kenangan kepada kenyataan, dan juga bersiap mengganti memori yang lama dengan kejadian baru. Asma tahu, patah hati menjadikan dia untuk terus melanjutkan hidup dan mulai memaafkan atas kekecewaan yang menyakiti hatinya.

Dalam memotivasi diri, Asma juga tidak terlepas dari sikapnya yang menjadikan hambatan sebagai suatu tantangan. Mengatasi tantangan akan membuat seseorang mampu mengembangkan diri (Goleman, 2006). Asma menjadikan hambatan yang datang dari orang-orang di sekitarnya menjadi sebuah tantangan baru untuk menguji konsistensinya pada apa yang telah ia jalani. Tantangan yang datang justru memperkuat prinsip agama Asma sebagai perempuan muslimah untuk menjaga diri lebih baik dari sebelumnya. Berikut kutipannya: "Tidak bersalaman atau bersentuhan dengan lelaki, kecuali keluarga, dan tidak lagi pacaran. Tidak peduli jika menjadi perbincangan di kantor. Asma menerimanya sebagai tantangan baru." (Nadia, 2016, hal. 90).

\section{Kemampuan Membina Hubungan}

Kemampuan sosial memungkinkan seseorang membentuk dan mempertahankan hubungan, untuk menggerakkan orang lain, membina kedekatan hubungan, meyakinkan, serta membuat orang-orang lain merasa nyaman (Goleman, 2006). Seseorang yang memiliki kemampuan ini akan sukses dalam bidang apapun yang berkaitan dengan sosial. Mereka juga tentunya mampu berinteraksi dengan baik. Tokoh perempuan muslimah dalam novel memiliki kecakapan sosial yang mendukung keberhasilan dalam pergaulannya dengan orang lain. hal. ini dibuktikan 
dengan kemampuannya membina hubungan yang meliputi menciptakan kedekatan hubungan, membangun kenyamanan, mempertahankan hubungan, dan menggerakkan orang lain.

\section{Tabel 3. Hasil Penelitian Kemampuan Membina Hubungan}

\begin{tabular}{|c|c|c|}
\hline No & Fokus & Hasil \\
\hline 1. & $\begin{array}{l}\text { Kemampuan } \\
\text { tokoh perempuan } \\
\text { muslimah } \\
\text { membina } \\
\text { hubungan }\end{array}$ & $\begin{array}{l}\text { a. Kemampuan tokoh perempuan muslimah dalam menciptakan } \\
\text { kedekatan hubungan. } \\
\text { b. Kemampuan tokoh perempuan muslimah dalam } \\
\text { mempertahankan hubungan yang terjalin. } \\
\text { c. Kemampuan tokoh perempuan muslimah dalam membangun } \\
\text { kenyamanan untuk orang lain. } \\
\text { d. Kemampuan tokoh perempuan muslimah dalam menggerakkan } \\
\text { orang lain ke arah yang positif. }\end{array}$ \\
\hline
\end{tabular}

Tokoh Asma mampu menciptakan kedekatan hubungan dengan pasien-pasien lain dan bahkan memberi semangat agar mampu melawan penyakit yang menyerang tubuh mereka, sama sepertinya. Asma yang sedang dilanda penyakit tidak membuatnya terus menerus berdiam diri meratapi kondisinya, ia justru berkomunikasi dan menciptakan kedekatan dengan pasien-pasien lain. Justru, ia mulai membangun persahabatan dengan mencatat nama dan alamat serta nomor ponsel mereka. "Asma tak hanya memberikan semangat kepada sesama pasien yang ditemui saat check up, atau ketika sama-sama dirawat, melainkan membangun persahabatan. Dibantu Sekar, Asma mencatat nama dan alamat serta nomor ponsel mereka" (Nadia, 2016, hal. 243). Tidak sampai di situ saja, Asma bahkan secara rutin menyapa lewat SMS atau e-mail. Dalam kondisinya yang kurang sehat, ia justru banyak bertemu, mengenal, bahkan membangun persahabatan dengan orang-orang yang tengah berjuang melawan penyakit, sama sepertinya.

Tidak hanya mampu menciptakan kedekatan hubungan dengan pasien-pasien lain di rumah sakit, Asma juga mampu membuat orang yang mengenalnya merasa nyaman dengan dirinya. Seseorang dengan kecakapan emosional mampu membuat orang lain merasa nyaman (Goleman, 2006). Sebagai perempuan muslimah, ia menyadari bahwa Islam memang mengajarkan pada umatnya untuk membangun silaturahmi bagi sesama. Asma memang termasuk tipe orang yang ramah dan menyenangkan, dirinya selalu memiliki cara tersendiri untuk membuat orang nyaman. hal. ini terlihat dari jalan pikiran tokoh lain, yakni Sunny yang bekerja sebagai tour guide. "Menurutnya ada berbagai macam tipe tamu, dari yang ramah dan baik serta menyenangkan seperti Asma. Sunny menyodorkan selembar kartu nama, dan meminta tamu dari Indonesianya itu berjanji untuk menyurati" (Nadia, 2016, hal. 59). Sunny tetap ingin menjalin hubungan dengan Asma, karena ia merasa nyaman dengan sikap tamu dari Indonesia tersebut.

Asma juga mampu membangun kenyamanan saat menjalin hubungan dengan kekasihnya, yakni Dewa. Ia menggunakan caranya sendiri untuk membuat orang terdekatnya merasa nyaman dengan mengerti kebutuhan yang diperlukan. Setiap kali Dewa berkunjung pada rumahnya, Asma selalu melibatkan Dewa dalam setiap pekerjaan yang dilakukannya. Berikut kutipannya: "Gadis mungilnya suka melibatkan Dewa, hingga tak merasa seperti orang asing. Memberi kesempatan padanya untuk berbaur, dan mengenal dekat penghuni rumah" (Nadia, 2016, hal. 
105). Mampu memahami perasaan orang lain dan memenuhi kebutuhannya menunjukkan adanya bakat emosional (Goleman, 2006).

Selain membangun kenyamanan, Asma juga tipe orang yang suka mempertahankan hubungan yang telah terjalin. Berikut kutipannya: "Kali ini Asma memastikan sehelai kartu nama itu tersimpan rapi di dompetnya. Meskipun tak pernah lagi bertemu, persahabatannya dengan Sunny berlanjut. Mereka masih saling mengirim kabar" (Nadia, 2016, hal. 59). Hal ini sengaja dilakukan Asma untuk tidak kehilangan kontak dan bisa terus menjalin hubungan dengan Sunny, meski sudah tidak lagi bertemu. Persahabatan keduannya masih terus berlanjut, dengan masih saling mengirim kabar. Keduanya memang sudah tidak pernah lagi bertemu, namun zaman yang semakin maju mampu memudahkan mereka untuk tetap menjalin persahabatan. Jarak yang membentang jauh tidak menghentikan persahabatan mereka. Persahabatan mereka tetap terjalin meski tanpa adanya pertemuan.

Dalam membina hubungan, Asma juga berusaha mempertahankan hubungannya bersama Zhongwen dengan tidak memberi kabar yang kurang baik mengenai kondisi tubuhnya saat ini. "Asma tak ingin merusak hubungan akrab yang terjalin dengan menebar kecemasan. Dia bisa merasakan kepedulian lebih yang dimiliki lelaki itu padanya, tetapi tidak bisa mendeteksi lebih jauh" (Nadia, 2016, hal. 187). Asma pun tidak berani membayangkan hal-hal romantis akan tercipta di antara keduanya. Ia takut harapan-harapannya itulah yang justru membuat hubungan akrab keduanya berakhir. Semakin terampil secara sosial, semakin baik seseorang mengendalikan sinyal serta berhati-hati untuk memastikan tidak ada luapan emosi yang dapat merusak perjumpaan (Goleman, 2006).

Kemampuan Asma dalam membina hubungan juga diketahui dari kemampuannya yang pandai menggerakkan orang lain. Dilihat dari banyaknya teman Asma yang menganggap dirinya sebagai pendengar sekaligus terapis cinta yang baik. Berikut kutipannya: "Bahkan sampai saat ini, teman-teman sekitar sering menganggap Asma, pendengar dan terapis yang baik soal cinta. Setelah mendengar kalimat-kalimat yang diucapkannya dengan lugas, teratur, dan lebih terkesan sebagai penyemangat" (Nadia, 2016, hal. 27). Kemampuan yang dimiliki dapat membuat seseorang menjadi ahli terapi atau konselor yang kompeten (Goleman, 2006). Tidak sedikit teman-teman semasa sekolahnya yang berbagi masalah cinta demi mendapat nasihat dari Asma. Menurut mereka, Asma adalah seseorang yang handal memberikan nasihat-nasihat atas persoalan yang dikeluhkan mereka. Kalimatkalimat yang diucapkan Asma dengan lugas, teratur, dan terkesan sebagai penyemangat bagi teman-temannya yang menghadapi masalah. Kalimat-kalimat itulah yang membuat kebanyakan teman Asma menjadi semangat dan merasa bahwa segala sesuatu menjadi lebih mudah untuk dijalani.

Orang yang sering dicari pada saat kebutuhan emosi mendesak dan mampu menolong orang lain menenangkan perasaannya termasuk seseorang yang memiliki bekal sosial berharga (Goleman, 2006). Asma telah menggerakkan orang lain untuk menghadapi persoalan sekaligus memberi pengaruh baik melalui kalimatkalimatnya. Selain itu, Asma juga mampu menggerakkan orang lain untuk semakin mendekatkan diri pada Yang Maha Kuasa. hal. ini benar dilakukannya pada pria yang dicintainya, yakni Zhongwen. Tokoh Asma mampu menuntun Zhongwen untuk merasakan kerinduan pada kekuatan Mahabesar. Berikut kutipannya: "Kebutuhan yang menguasainya saat ini, lambat laun tidak lagi hanya pada Ashima, tetapi terhadap kekuatan Mahabesar, yang sejak lahir tak pernah dihiraukan. Dan, 
gadis itu menuntunnya" (Nadia, 2016, hal. 153). Padahal, sebelumnya lelaki itu tak pernah menghiraukan hal. tersebut, bahkan sejak lahir pun tidak pernah sama sekali. Lelaki yang tengah mencintai Asma, kini mulai merasakan perasaan serupa pada Yang Maha Kuasa. Bukan hanya pada gadis itu saja. Rupanya Asma telah menuntun Zhongwen untuk semakin mendekatkan diri pada Tuhan. Kerinduan Zhongwen pada Asma yang menjadi kebutuhan, lambat laun menjadi kerinduan terhadap kekuatan Mahabesar pula.

Tidak hanya menuntun Zhongwen pada kerinduan terhadap kekuatan Sang Mahabesar semata saja. Yang menakjubkan, Asma mampu menggerakkan keyakinan Zhongwen untuk memeluk agama Islam. Bahkan, menurut Zhongwen, Allah telah memberikan hidayah padanya melalui gadis yang dicintainya itu. Asma telah menggerakkan hati sekaligus keyakinan Zhongwen untuk memeluk agama Islam. Melalui kisah cinta mereka, yang membawa Zhongwen pada keyakinan akan segala hal, yang tidak terlepas dari campur tangan Allah. "Dan skenario-Nya, cara Allah mengulurkan hidayah melalui gadis berkerudung cerah itu, menurut Zhongwen sangat indah. Menyentuh" (Nadia, 2016, hal. 255).

\section{PENUTUP}

Kecerdasan emosional tokoh perempuan muslimah dalam novel Assalamualaikum Beijing terdiri dari tiga aspek, yaitu (1) kemampuan mengelola emosi, (2) kemampuan memotivasi diri, dan (3) kemampuan membina hubungan. Pada kemampuan mengelola emosi, ditunjukkan melalui sikap tokoh perempuan muslimah dalam mengendalikan dorongan hati, mengatasi kecemasan, serta menangani kesedihan. Pada kemampuan memotivasi diri, ditunjukkan melalui keinginan tokoh perempuan muslimah untuk berhasil, menjadikan situasi lain maupun masalah diri sebagai motivasi untuk bangkit, dan menjadikan hambatan yang menghadangnya sebagai suatu tantangan tersendiri. Pada kemampuan membina hubungan, ditunjukkan melalui sikap tokoh perempuan muslimah dalam menciptakan kedekatan hubungan, membangun kenyamanan, mempertahankan hubungan, mengutamakan orang lain, serta menggerakkan orang lain ke arah yang lebih positif.

Berdasarkan hasil penelitian dan pembahasan mengenai kecerdasan tokoh emosional perempuan muslimah dalam novel Assalamualaikum Beijing karya Asma Nadia, disarankan bagi pembaca untuk menjadikan penelitian ini sebagai pelajaran dalam menggali hal-hal baik sebagai perempuan muslimah yakni memahami emosi dengan baik dan menjadikan norma-norma agama sebagai landasan kuat dalam berperilaku. Dalam dunia sastra maupun pendidikan, novel Assalamualaikum Beijing diharapkan mampu menjadi bahan bacaan, referensi, sekaligus acuan bagi siswa untuk cerdas dalam mengelola emosi dan tetap mengedepankan agama seperti tokoh perempuan muslimah dalam novel tersebut. Penelitian ini cukup jauh dari kesempurnaan, oleh karena itu disarankan bagi peneliti selanjutnya yang membahas mengenai kecerdasan emosional tokoh perempuan muslimah dalam karya sastra hendaknya juga mengkaji aspek-aspek lain yang merupakan latar belakang dan unsur-unsur pembangun karya sastra dengan persiapan yang lebih matang. 


\section{DAFTAR PUSTAKA}

Agustian, A.G. (2001). Esq Power Sebuah Inner Journey melalui Al-Ihsan. Jakarta: Arga. Asy-Sya'rawi. (2013). Suami Istri Berkarakter Surgawi. Jakarta: Pustaka Al Kautsar.

Atmazaki. (2007). Ilmu Sastra: Teori dan Terapan. Padang: UNP Press.

Daryanto. (2006). Kamus Bahasa Indonesia Lengkap. Surabaya: Apollo.

Deswika. (2012). Struktur dan Nilai Religius dalam Novel Rinai Kabut Singgalang Karya Muhammad Subhan. Jurnal FBS Universitas Negeri Padang, 1(1), 478-486. Diambil dari https://www.neliti.com/publications/119595/struktur-dannilai-religius-dalam-novel-rinai-kabut-singgalang-karya-muhammad-su

Emda A. (2017). Kedudukan Motivasi Belajar Siswa dalam Pembelajaran. Jurnal Lantanida, 5(2), 93-196. Diambil dari https://jurnal.arraniry.ac.id/index.php/lantanida/article/view/2838/2064

Goleman, D. (2006). Emotional Intelegence: Mengapa Eq Lebih Penting Dari Pada Iq Jakarta: PT Gramedia Pustaka Utama

Hanafi, R. (2010). Kecerdasan Spiritual, Kecerdasan Emosional dan Performa Auditor. JAAI Universitas Islam Sultan Agung Semarang, 14(1), 29-40. Diambil dari

http://webcache.googleusercontent.com/search?q=cache:E4bX1Hu6SmoJ:jo urnal.uii.ac.id/JAAI/article/download/2244/2046+\&cd=1\&hl=en\&ct=clnk $\underline{\& l=\mathrm{id}}$

Marwan. (2019). Kecerdasan Emosi Tokoh dalam Novel Setegar Ebony Karya Asih Karina. Jurnal FKIP UNTAN Pontianak, 8(8), 1-8. Diambil dari http://jurnal.untan.ac.id/index.php/jpdpb/article/view/34782

Mujib \& Mudzakir. (2002). Nuansa-Nuansa Psikologi Islam. Jakarta: Raja Garafindo Persada.

Nadia, A. (2016). Assalamualaikum Beijing. Depok: AsmaNadia Publishing House.

Nurgiyantoro, B. (2005). Teori Pengkajian Fiksi. Yogyakarta: UGM Press.

Novera. (2017). Citra Perempuan dalam Novel Pulang Karya Leila S. Chudori. Jurnal Bahasa dan Sastra, 5(1), 1-15. Diambil dari https://ejournal.unp.ac.id/index.php/ibs/article/download/9863/7333

Setyorini. (2016). Kepribadian Tokoh Utama dan Nilai Pendidikan Kerja Keras pada Novel Entrok Karya Okky Madasari dan Relevansinya dengan Pembelajaran Sastra di Perguruan Tinggi (Kajian Psikologi Sastra). Jurnal S2 Pendidikan Bahasa Indonesia, 1(1). Diambil dari https://jurnal.fkip.uns.ac.id/index.php/s2indo/article/view/9203

Supandu. (2017). Perempuan dalam Novel Dakwah: Kajian Karya Asma Nadia dalam Perspektif Hall. Jurnal Lakon, 6(1), 1-12. Diambil dari https://ejournal.unair.ac.id/LAKON/article/view/6789 